\title{
Gross precipitation and throughfall chemistry in legume species planted in Northeastern México
}

\author{
José Návar • Jorge Méndez González • \\ Humberto Gonzalez
}

Received: 3 April 2008 / Accepted: 15 October 2008 / Published online: 29 October 2008

(C) The Author(s) 2008. This article is published with open access at Springerlink.com

\begin{abstract}
Plant cover modifies throughfall chemistry, and the solute concentration is dependent on the plant species at any given site. The chemistry of gross rainfall and throughfall of four endemic species planted in northeastern Mexico was evaluated from March 1996 to March 1997. Chemical solutes measured included Ca, K, $\mathrm{Mg}, \mathrm{Na}, \mathrm{Fe}, \mathrm{Mn}, \mathrm{Cu}$, and $\mathrm{Zn}$. Dry deposition and canopy leaching fluxes were estimated following the canopy budget model. Variance analyses tested the statistical dependence of the total and net fluxes on the species and seasons. Regression analysis tested the dependence of chemical concentrations on rainfall depth and lag time between rains. A total of 52 rainfall events were recorded during the study period summing $523 \mathrm{~mm}$. Significant differences were noted on the total and net fluxes between
\end{abstract}

Responsible Editor: Tibor Kalapos.

J. Návar $(\triangle)$

CIIDIR-IPN, Unidad Durango,

Calle Sigma s/n. Fracc. 20 de Noviembre II,

Durango, Dgo 34220, México

e-mail: jnavar@ipn.mx

J. M. González

Departamento Forestal,

Universidad Autónoma Agraria 'Antonio Narro',

Buenavista,

Saltillo, Coahuila, México

H. Gonzalez

Facultad de Ciencias Forestales, UANL,

Carr Nacional km 145,

Linares, N.L., Mexico 67700 the plant species. For total flux, average throughfall $\left(37.8 \mathrm{~kg} \mathrm{ha}^{-1}\right.$ year $\left.^{-1}\right)$ almost doubled the flux of solutes compared to rainfall $\left(24.1 \mathrm{~kg} \mathrm{ha}^{-1}\right.$ year $\left.^{-1}\right)$. Pithecellobium ebano (Berland.) C.H. Mull. (43.3 $\mathrm{kg} \mathrm{ha}^{-1}$ year $\left.{ }^{-1}\right)$, Acacia berlandieri Benth. (38.7 $\mathrm{kg} \mathrm{ha}^{-1}$ year $\left.^{-1}\right)$, and Pithecellobium pallens (Bent.) Standl. (38.4 $\mathrm{kg} \mathrm{ha}^{-1}$ year $^{-1}$ ) recorded the highest total flux of solutes, and Acacia rigidula Benth. (30.9 $\mathrm{kg} \mathrm{ha}^{-1}$ year $^{-1}$ ) the smallest. Chemical solutes showed significant differences for total and net fluxes. Ca was the dominant cation with $48 \%$ and $52 \%$ of the total constituent flux for rainfall and throughfall, respectively. However, K, $\mathrm{Mg}$ and $\mathrm{Cu}$ approximately doubled in throughfall in contrast to gross rainfall. Species with the largest aboveground biomass had lower throughfall volumes (i.e., higher interception rates) but higher chemical solute inputs to the forest floor. Rainfall depth and lag time between rains explained part of the variation for most species, stressing the partial dependence of the washing effect and the amount of dry deposition on canopies. This research discusses the importance and the sources of incoming solutes on the studied plant species.

Keywords Gross rainfall · Native leguminous species · Throughfall chemistry

\section{Introduction}

The role of gross precipitation as a major input of chemicals in ecosystems has been a cause of major 
concern in the last decades (Fahey et al. 1988; Gesper and Holowaychuk 1970; Parker 1983). In addition to rainfall, plants play a pivotal role in modifying the input of chemical solutes via throughfall (Gesper and Holowaychuk 1970) and stemflow (Parker 1983; Whitford et al. 1997). The chemistry of throughfall is made up of bulk deposition, dry deposition and canopy leaching, amongst other sources. Dry-fall collects on foliage, branches and stems of shrubs and is related to natural and anthropogenic emissions. The biological activity of micro-organisms in the canopies may also contribute to the availability of ions. Canopy leaching is another source of solute input in throughfall that may be important in several ecosystems. Other ion sources are likely explained by the different phenological phases, tissue exudation and decomposition, among other factors.

In arid and semi-arid landscapes, the architecture of trees, in addition to the typical sources of chemical solutes in canopies, generally increases ion concentrations in throughfall and stemflow, and consequently in the nutrient availability of soils, creating islands of soil moisture (Návar and Bryan 1990; Whitford et al. 1997) and fertility (Ambatzis et al. 2003; Breman and Kessler 1995; Jonsson et al. 1999; Schade and Hobbie 2005; $\mathrm{Su}$ et al. 2002; Whitford et al. 1997) relative to areas outside the canopy, which are characterized as arid, infertile soils (Schlesinger and Pilmanis 1998). Therefore, additional sources of several chemical solutes are of paramount importance in places where they are not readily available (Fahey et al. 1988) or where weathering processes are slow (Newman 1995).

In the islands of fertility of arid and semi-arid ecosystems, elements such as N, C and P are the most widely studied (Ambatzis et al. 2003; Breman and Kessler 1995; Whitford et al. 1997; Schade and Hobbie 2005; Wezel et al. 2000), although the elemental composition of plants has demonstrated that the most important 12 elements are $\mathrm{C}, \mathrm{H}, \mathrm{O}, \mathrm{N}, \mathrm{S}, \mathrm{P}$, $\mathrm{Cl}, \mathrm{Ca}, \mathrm{Mg}, \mathrm{K}, \mathrm{Na}$ and Fe (Mohr and Schopfer 1995). Therefore, studies dealing with the understanding of the concentrations and fluxes of cations such as Calcium (Ca), Magnesium (Mg), Potassium (K), Sodium $(\mathrm{Na})$, Copper $(\mathrm{Cu})$, Manganese $(\mathrm{Mn})$, Zinc $(\mathrm{Zn})$ and Iron $(\mathrm{Fe})$ are required in order to understand plant nutrition in arid and semi-arid infertile soils, since most of the micro elements are important to plant nutrition and semi arid soils are deficient in these elements (Vlek 1985).
Moreover, studies dealing with the chemical concentration of throughfall are common in canopies of temperate and tropical vegetation (Filoso et al. 1999; Gauquelin et al. 1992; Germer et al. 2007; Parker 1983; Potter et al. 1991; Schreiber et al. 1990; Switzer et al. 1988; Tobón et al. 2004; Zimmermann et al. 2007). However, there is little research on the role that arid and semi-arid shrubs play on the net flux of the cations mentioned above into soils.

The objectives of this research were: i) to evaluate the concentration of eight chemical solutes $(\mathrm{Ca}, \mathrm{Mg}$, $\mathrm{K}, \mathrm{Na}, \mathrm{Cu}, \mathrm{Mn}, \mathrm{Zn}$ and $\mathrm{Fe}$ ) in gross rainfall and throughfall of each of four species: Acacia rigidula Benth., Acacia berlandieri Benth., Pithecellobium ebano (Berland.) C.H. Mull. and Pithecellobium pallens (Bent.) Standl., and ii) to estimate total and net fluxes, and iii) to investigate whether there are significant differences in throughfall chemistry among plant species and to discuss the potential sources of throughfall chemistry variation. The hypotheses tested were that constituent inputs (total and net) are similar between: a) the species and b) the chemical solutes.

\section{Materials and methods}

An experimental site was placed at the Faculty of Forest Sciences of the University of Nuevo Leon, FCF-UANL $\left(24^{\circ} 47^{\prime} \mathrm{N}, 99^{\circ} 32^{\prime} \mathrm{W}\right.$, at an elevation of $350 \mathrm{~m}$ above sea level, masl). The FCF-UANL is located $8 \mathrm{~km}$ south of Linares, Nuevo Leon, Mexico. The region is within the physiographic province of the northern coastal plains of the Gulf of Mexico and is characterized by a semi-arid, sub-tropical climate. Mean annual temperature and precipitation are $21^{\circ} \mathrm{C}$ and $760 \mathrm{~mm}$, respectively. The standard deviation of annual rainfall is $260 \mathrm{~mm}$. Approximately $80 \%$ of the annual precipitation is delivered between May and October. Potential annual evapotranspiration, estimated using the Thornthwaite method, is $1,150 \mathrm{~mm}$ (Návar et al. 1994). Deep Vertisols (0.30-1.00 m), which shrink and swell noticeably in response to soil moisture content, dominate the lowlands of the plains (Woerner 1991).

The study was conducted on shrubs planted during 1984. Plantings with the species $A$. rigidula, $A$. berlandieri, $P$. pallens and $P$. ebano were conducted on a randomized block design. The plant species are distributed widely from the Tamaulipan thornscrub of 
the plains to the Submontane Matorral in the Eastern Sierra Madre mountain range. They are commercially important for forage and fuelwood. Each block contains 16 shrubs, with three blocks per species. Four plants of each of four species were selected to measure gross rainfall and throughfall chemistry and depth. The dasometric characteristics of the studied plant species are described in Table 1. The top height and basal diameter of leguminous tree species are similar to the average values reported for the Tamaulipan thornscrub plant community evaluated in a similar physiographic region. Romero (1999) reported mean figures for the Tamaulipan thornscrub similar to those reported for the studied shrubs.

Gross rainfall $(\mathrm{Pg})$ was measured using 4-liter cylindrical collectors with polyethylene funnels, $20 \mathrm{~cm}$ in diameter, on top of the collector to facilitate rainfall entrance and avoid splashing and evaporation. Rainfall collectors were placed on a wooden box with a height of $42 \mathrm{~cm}$ to impede rain splashing into the collectors. In total, four gross rainfall collectors were placed in openings, each one next to each forest plantation monitored for throughfall. Throughfall (Pe) was measured below the canopies of each of four shrubs per each species in a similar manner used to collect gross rainfall. Throughfall collectors were placed below the canopy at an average distance of $45 \mathrm{~cm}$ from the main stem. Polyethylene mesh (screen, $2.5 \mathrm{~mm}$ in size) was placed on top of the funnels to isolate throughfall from leaves, branches, and other potential sources of contamination. After rainfall events, collectors were emptied while recording total volume and depth, and throughfall samples were collected for chemical analysis. Gross rainfall and throughfall were collected within $12 \mathrm{~h}$ after each rainfall event to prevent evaporation from collectors and chemical reactions with potential sources of contamination. Collectors were washed with hydrochloric acid and deionized water after the collection of gross rainfall and throughfall, and they were randomly relocated within the canopy radius described above in order to understand the full throughfall depth and the spatial variation of the throughfall chemistry.

In the laboratory, collected samples of gross rainfall and throughfall were filtered and frozen until chemical analysis was conducted. The concentrations of $\mathrm{Ca}, \mathrm{K}$, $\mathrm{Mg}, \mathrm{Na}, \mathrm{Fe}, \mathrm{Mn}, \mathrm{Cu}$ and $\mathrm{Zn}$ were estimated with an atomic absorption spectrophotometer (Perkin Elmer AA3000). The detection limits in parts per million were: $\mathrm{Ca}(0.09), \mathrm{K}(0.04), \mathrm{Na}(0.03), \mathrm{Mg}$ (0.01), Mn (0.0001), $\mathrm{Fe}(0.0001), \mathrm{Zn}(0.0001)$ and $\mathrm{Cu}(0.0001)$. The relative standard deviation on repeated measures of internal quality control never surpassed $5 \%$ for each chemical constituent. Each precipitation event for each collector under each shrub was independently analyzed. In total we analyzed 1,040 samples (52 rainfall events, four plant species plus the gross rainfall and four replicates).

Plant biomass was calculated from the non-linear equation developed by Návar et al. (2004) for Tamaulipan thornscrub species (i.e. $b t=0.059 * \mathrm{Db}^{2.43} * \mathrm{No}$ $\mathrm{S}$; where: $\mathrm{bt}=$ total aboveground biomass $(\mathrm{kg}$ per shrub)), $\mathrm{Db}=$ basal diameter, No $\mathrm{S}=$ number of stems and the total constituent flux, tcf, $\left(\mathrm{Kg} \mathrm{ha}^{-1}\right)$ was regressed to constituent fluxes in throughfall and throughfall amount.

Data analysis The major sources of variation of the solute fluxes were statistically determined by variance analysis. That is, the experiment fitted well a randomized block design with two major sources of variation: species including the control (5) and chemical solutes (8) with four replicates. Mean throughfall solute concentrations and net fluxes were tested for differences between species and chemicals with Tukey`s honest

Table 1 The mean dasometric characteristics (confidence intervals, $\alpha=0.05$ ) of four legume species planted inside the Tamaulipan thornscrub in northeastern Mexico

\begin{tabular}{|c|c|c|c|c|}
\hline \multirow[t]{2}{*}{ Plant species } & \multicolumn{2}{|l|}{ Average } & \multirow[t]{2}{*}{ No. of stems/Plant } & \multirow[t]{2}{*}{ Vertical projection of canopy $\left(\mathrm{m}^{2}\right)$} \\
\hline & Height (m) & Diameter $(\mathrm{cm})$ & & \\
\hline Acacia rigidula & $2.50 \pm(0.68)$ & $1.40 \pm(0.24)$ & $18.2 \pm(3.54)$ & $3.89 \pm(1.26)$ \\
\hline Acacia berlandieri & $2.63 \pm(0.87)$ & $1.85 \pm(0.38)$ & $9.8 \pm(4.58)$ & $4.80 \pm(0.95)$ \\
\hline Pithecellobium ebano & $3.01 \pm(0.46)$ & $6.35 \pm(0.26)$ & $1.0 \pm(1.85)$ & $3.18 \pm(1.37)$ \\
\hline Pithecellobium pallens & $3.80 \pm(0.49)$ & $2.78 \pm(0.49)$ & $6.6 \pm(2.36)$ & $5.26 \pm(1.12)$ \\
\hline
\end{tabular}

Vertical projection of the canopy was measured as the area the canopy shades on the ground 
significant difference (HSD) mean separation test. For the species, to compare mean fluxes we used the contrast statistic, since the experimental design is set to test for differences between the control and the species and between the species themselves (i.e. two Acacia spp and two Pithecellobium spp), with a probability of $\alpha=0.05$. The ANOVA was conducted on the total and net fluxes. The element concentration $\left(\mathrm{mg} \mathrm{L}^{-1}\right)$ was also analyzed by variance analysis with two major sources of variation: seasons (4) and the species, including the control (5). Seasons were determined following the calendar year, i.e., spring from March 21st to June 20th.

Linear regression and non-linear regression equations were fitted to either the concentration or net flux of each constituent and gross rainfall depth and lag time between rainfall events. The latter statistical technique tested the dependence of chemical concentration or net flux on the rainfall depth and lag time between rainfalls, and gives information on the intercept and slope of these relationships which could have some meaningful interpretation. In order to fit the mathematical functions, first the solute $\left(\mathrm{mg} \mathrm{L}^{-1}\right)$ or the net flux $\left(\mathrm{Kg} \mathrm{ha}^{-1} \mathrm{y}^{-1}\right)$ of the constituent and rainfall depth $(\mathrm{mm})$ or lag time between rainfalls (days) were graphed. Following, the SAS statistical software v. 8.0 was used to carry out the ANOVA and regression analysis (SAS 2000). Throughfall depth was regressed against aboveground biomass and an equation is developed to understand how plant biomass controls interception loss. Aboveground biomass partially controls total and net fluxes; therefore these constituent fluxes were regressed against total estimated aboveground biomass.

\section{Results}

A total of 52 gross rainfall events were recorded during the period of March, 1996-March, 1997. In all 52 rainfall events, the total recorded rainfall depth was $522.8 \mathrm{~mm}$, with an average and standard deviation of $10.5 \mathrm{~mm}$ and $16.6 \mathrm{~mm}$, respectively. Deep convection by mid-latitude disturbances and cyclone activity from the Gulf of Mexico promoted most rainfall in the region. The hurricanes "Dolly" and "Hernan" produced two major storms with electrical activity. Of all the rainfall events, $60 \%$ had a depth of less than $5 \mathrm{~mm}, 20 \%$ between $5 \mathrm{~mm}$ and $10 \mathrm{~mm}$ and $5 \%$ between $50 \mathrm{~mm}$ and $70 \mathrm{~mm}$ in depth. Seventy percent of rainfall events had antecedent periods of $1-5$ days and $30 \%$ had 5-40 days. $63 \%$ of gross rainfall depth was recorded between June and October of 1996.

The species showed significant differences in throughfall percentages (throughfall depth/rainfall depth *100) with mean values of $94.0 \%{ }^{\mathrm{A}}, 81.3 \%{ }^{\mathrm{B}}, 92.4 \%{ }^{\mathrm{A}}$ and $86.7 \%{ }^{\mathrm{AB}}$ for A. rigidula, P. pallens, A. berlandieri and $P$. ebano, respectively. Percentages with the same letter are statistically different $(p=0.0001)$. That is, $P$. pallens had the smallest throughfall percentages. The significant differences could be associated with total aboveground biomass, since throughfall and total aboveground biomass, bt, fitted well with a negative linear relationship (i.e. throughfall $(\%)=101.24-3.38 \mathrm{bt} ; \mathrm{r}^{2}=0.71 ; P=$ $0.0001 ; n=16)$. That is, shrubs with large aboveground biomass had small throughfall values and vice versa. Biomass components (foliage, branches and boles) provide surfaces to wet and to evaporate intercepted rainfall. A positive linear relationship with high statistical significance (with all $\mathrm{r}^{2}$ values above 90\%) was found between gross rainfall and throughfall depth for all four plant species (Fig. 1).

Fluxes of chemical solutes

The chemical fluxes in gross rainfall showed the following trend: $\mathrm{Ca}>\mathrm{Na}>\mathrm{K}>\mathrm{Mg}>\mathrm{Fe}>\mathrm{Zn}>\mathrm{Mn}>\mathrm{Cu}$ (Table 2). Therefore, $\mathrm{Ca}$ dominated the total flux contribution of the species (49\%), followed by $\mathrm{Na}$ (37\%) and $\mathrm{K}(12 \%)$, while $\mathrm{Cu}$ contributed a negligible total flux $(0.03 \%)$. The ANOVA showed significant differences in total fluxes between chemical solutes $(P=0.0001)$, unlike the plant species including the control $(P=0.11)$. According to the mean comparisons of Tukey, the chemical solutes had a significan different contribution, following the pattern described below in total element flux $\left(\mathrm{kg} \mathrm{ha}^{-1}\right.$ year $\left.^{-1}\right)$ : Ca $\left(18.3^{\mathrm{A}}\right), \mathrm{Na}\left(9.2^{\mathrm{B}}\right), \mathrm{K}\left(6.0^{\mathrm{B}}\right), \mathrm{Mg}\left(1.4^{\mathrm{C}}\right), \mathrm{Fe}\left(0.09^{\mathrm{C}}\right), \mathrm{Zn}$ $\left(0.04^{\mathrm{C}}\right), \mathrm{Mn}\left(0.03^{\mathrm{C}}\right)$, and $\mathrm{Cu}\left(0.026^{\mathrm{C}}\right)$. Although the ANOVA showed that the plant species contributed in a similar way to chemical flux; the contrast statistic showed that the Acacias (A. rigidula and A. berlandieri) had smaller total element fluxes than Pithecellobiums ( $P$. pallens and $P$. ebano $)(p=0.017)$. In general, the former species recorded smaller total aboveground biomass estimates. A regression equation (Total Deposition $=2.7 \mathrm{~B}+27.7 ; \mathrm{r}^{2}=0.59 ; p=0.0001$; $n=16$ ) indicated that total aboveground biomass (B) partially explains the total flux contribution of the 
Fig. 1 The relationship between throughfall and gross rainfall for tour leguminous shrub species planted in northeastern Mexico
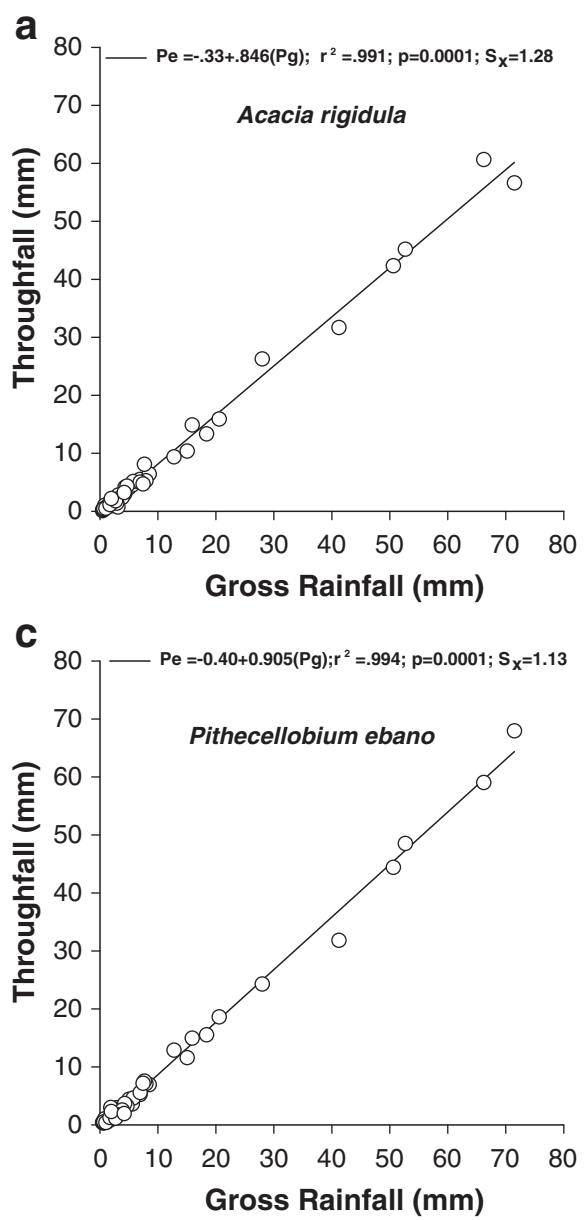

b

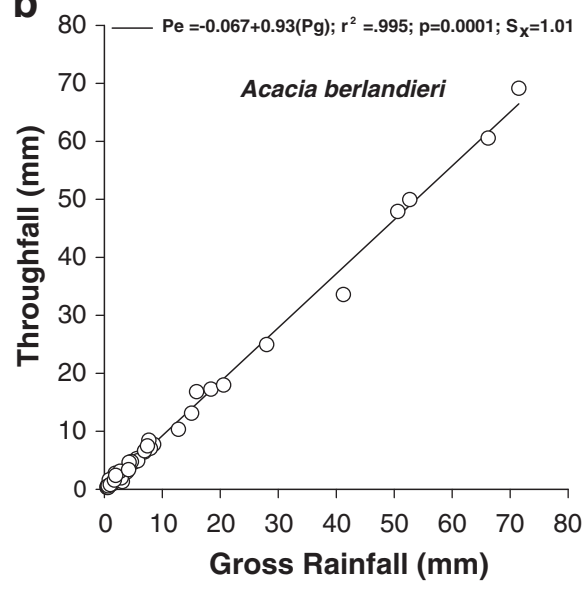

d

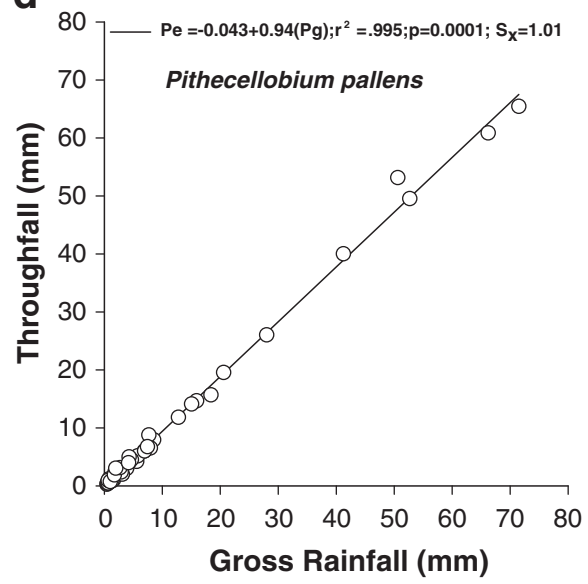

Table 2 The mean (confidence intervals, $\alpha=0.05)$ fluxes for several chemical solutes $\left(\mathrm{kg} \mathrm{ha}^{-1}\right.$ year $\left.^{-1}\right)$ in gross rainfall and throughfall for four species planted in northeastern Mexico

\begin{tabular}{|c|c|c|c|c|c|c|}
\hline \multirow[t]{2}{*}{ Element } & \multirow[t]{2}{*}{ Flux } & \multirow{2}{*}{$\begin{array}{l}\text { Rainfall }(\mathrm{Pg}) \\
\text { Control }\end{array}$} & \multicolumn{4}{|l|}{ Throughfall (Pe) } \\
\hline & & & A. rigidula & A. berlandieri & P. ebano & P. pallens \\
\hline \multirow[t]{2}{*}{$\mathrm{Ca}$} & Total & $11.74 \pm(2.53)$ & $14.17 \pm(4.71)$ & $20.62 \pm(6.98)$ & $24.53 \pm(8.54)$ & $20.39 \pm(6.097)$ \\
\hline & Net & & $2.43 \pm(0.52)$ & $8.88 \pm(3.56)$ & $12.79 \pm(7.6)$ & $8.64 \pm(6.3)$ \\
\hline \multirow[t]{2}{*}{$\mathbf{K}$} & Total & $2.83 \pm(0.72)$ & $7.09 \pm(1.84)$ & $6.80 \pm(1.69)$ & $7.57 \pm(1.63)$ & $5.72 \pm(1.16)$ \\
\hline & Net & & $4.26 \pm(1.08)$ & $3.97 \pm(2.58)$ & $4.74 \pm(2.8)$ & $2.89 \pm(1.7)$ \\
\hline \multirow[t]{2}{*}{ Mg } & Total & $0.56 \pm(0.18)$ & $0.94 \pm(0.46)$ & $1.62 \pm(1.56)$ & $1.95 \pm(0.73)$ & $1.69 \pm(0.78)$ \\
\hline & Net & & $0.38 \pm(0.12)$ & $1.06 \pm(0.87)$ & $1.39 \pm(3.8)$ & $1.13 \pm(1.5)$ \\
\hline \multirow[t]{2}{*}{$\mathbf{N a}$} & Total & $8.81 \pm(3.01)$ & $8.51 \pm(4.76)$ & $9.39 \pm(5.59)$ & $9.01 \pm(4.07)$ & $10.42 \pm(4.45)$ \\
\hline & Net & & $-0.30 \pm(0.10)$ & $0.58 \pm(0.32)$ & $0.20 \pm(0.13)$ & $1.61 \pm(0.75)$ \\
\hline \multirow[t]{2}{*}{$\mathrm{Cu}$} & Total & $0.008 \pm(0.0056)$ & $0.026 \pm(0.018)$ & $0.037 \pm(0.011)$ & $0.031 \pm(0.013)$ & $0.026 \pm(0.016)$ \\
\hline & Net & & $0.02 \pm(0.01)$ & $0.03 \pm(0.06)$ & $0.02 \pm(0.03)$ & $0.02 \pm(0.03)$ \\
\hline \multirow[t]{2}{*}{$\mathbf{F e}$} & Total & $0.075 \pm(0.055)$ & $0.110 \pm(0.31)$ & $0.101 \pm(0.29)$ & $0.109 \pm(0.30)$ & $0.091 \pm(0.034)$ \\
\hline & Net & & $0.04 \pm(0.02)$ & $0.03 \pm(0.10)$ & $0.03 \pm(0.13)$ & $0.02 \pm(0.06)$ \\
\hline \multirow[t]{2}{*}{ Mn } & Total & $0.025 \pm(0.020)$ & $0.031 \pm(0.016)$ & $0.040 \pm(0.012)$ & $0.038 \pm(0.015)$ & $0.033 \pm(0.017)$ \\
\hline & Net & & $0.01 \pm(0.005)$ & $0.02 \pm(0.01)$ & $0.01 \pm(0.01)$ & $0.01 \pm(0.01)$ \\
\hline \multirow[t]{2}{*}{$\mathbf{Z n}$} & Total & $0.044 \pm(0.013)$ & $0.040 \pm(0.085)$ & $0.036 \pm(0.098)$ & $0.037 \pm(0.077)$ & $0.039 \pm(0.012)$ \\
\hline & Net & & $0.00 \pm(0.001)$ & $-0.01 \pm(0.01)$ & $-0.01 \pm(0.02)$ & $-0.01 \pm(0.01)$ \\
\hline
\end{tabular}


species. That is, shrubs with the largest aboveground biomass produce the largest total constituent fluxes in throughfall, mainly stressing the effect of aerial biomass on dry deposition and canopy exchange.

In relation to the net element flux, the ANOVA showed significant differences between chemical solutes $(p=0.0001)$ and the plant species $(p=0.05)$. For chemical solutes, the following pattern emerged from the mean comparisons of Tukey: $\mathrm{Cu}\left(2.75^{\mathrm{A}}\right), \mathrm{Mg}$ $\left(1.76^{\mathrm{B}}\right), \mathrm{K}\left(1.40^{\mathrm{BC}}\right), \mathrm{Ca}\left(0.70^{\mathrm{CD}}\right), \mathrm{Mn}\left(0.42^{\mathrm{D}}\right), \mathrm{Fe}$ $\left(0.37^{\mathrm{D}}\right), \mathrm{Na}\left(0.06^{\mathrm{D}}\right)$ and $\mathrm{Zn}\left(-0.14^{\mathrm{D}}\right)$ (Table 2). That is, throughfall increased fluxes, in contrast to gross rainfall, on average, $\mathrm{Cu}(275 \%), \mathrm{Mg}(176 \%)$, and $\mathrm{K}$ $(140 \%)$. The remaining solutes although increased by more than $37 \%$ but less than $74 \%$, they were not significant different. Negative net fluxes were recorded for $\mathrm{Zn}$, which was reduced (14\%) by the plant species compared to gross rainfall, however, this element was not significantly different to $\mathrm{Na}, \mathrm{Fe}, \mathrm{Mn}$, and $\mathrm{Ca}$, which presented positive net fluxes in throughfall. Total aboveground biomass also explained partially the net flux variability, with the following regression equation: Net Flux $=0.51 \mathrm{~B}+5.4 ; \mathrm{r}^{2}=0.18 ; p=0.0028 ; n=16$.

For the plant species, the contrast statistic showed that $A$. berlandieri $(p=0.026)$ and P. ebano $(p=0.078)$ had the largest net constituent flux input into the soil compared to the rest of the semi arid species studied. The total average net flux contribution for all plant species for all solutes was $57 \%$ of the total flux measured in gross rainfall. At the plant species level, the contribution varied from $60 \%$ to $80 \%$ in $A$. berlandieri and $P$. ebano, respectively, and from $29 \%$ to $59 \%$ in $A$. rigidula and $P$. pallens, respectively, of the total flux recorded in gross rainfall.

\section{Concentration of chemical solutes}

Calcium was the dominant constituent concentration in both gross rainfall and throughfall. Ca concentration increased two to three orders of magnitude in throughfall compared to the concentration of gross rainfall for all seasons with the exception of the summer and fall ( $p=0.05$ ) (Fig. 2). Between the plant species, there were no significant differences in $\mathrm{Ca}$ concentrations for all seasons. However, P. ebano recorded the highest concentrations and $P$. pallens recorded the lowest (Fig. 2).

Plant cover significantly modified $\mathrm{Mg}$ concentrations for all seasons compared to the concentration in gross rainfall ( $p=0.05$ ) (Fig. 2). There were significant differences between the species only for the summer season. At this time, $P$. ebano recorded the largest $\mathrm{Mg}$ concentrations and $A$. berlandieri and $P$. pallens recorded the smallest ( $p=0.05$ ).

The concentration of $\mathrm{K}$ was greater in throughfall than in rainfall for all seasons except the fall. Between the plant species, there were statistical differences only during the summer. Again, P. ebano recorded the largest $\mathrm{K}$ concentrations and $A$. berlandieri and $P$. pallens recorded the smallest. On an annual basis, $A$. rigidula and $A$. berlandieri contributed to the largest $\mathrm{K}$ fluxes. Sodium concentrations in $\mathrm{Pe}$ and $\mathrm{Pg}$ were statistically similar for all seasons; although A. rigidula recorded the highest and $A$. berlandieri recorded the lowest concentrations (Fig. 2). The concentrations of sodium were significantly different in $\mathrm{Pe}$ and $\mathrm{Pg}$, but only for the summer. The species recorded similar concentrations of $\mathrm{Na}$ for all seasons.

The concentration of $\mathrm{Cu}$ was larger in $\mathrm{Pe}$ than in $\mathrm{Pg}$ for all seasons with the exception of fall. However, $\mathrm{Cu}$ concentrations were statistically similar for all of the studied plant species. Mn concentrations increased in $\mathrm{Pe}$ compared to the Mn concentration in Pg during the spring and summer $(p=0.05)$. During the fall and winter, the Mn concentrations were similar in Pe and Pg (Fig. 3). The concentrations of $\mathrm{Zn}$ were statistically different in Pe and Pg only for the summer, although the species recorded similar concentrations for all seasons. Fe concentrations were larger only during the spring and summer, and only for the species $A$. rigidula, $P$. ebano and $A$. berlandieri, which was a contrast to the Fe concentrations in $\operatorname{Pg}(p=0.05)$.

\section{Regression analysis}

The positive effect of $\mathrm{Pg}$ depth was statistically observed for several chemical solutes for several plant species. A positive relationship was observed between the net flux of $\mathrm{Ca}, \mathrm{Cu}, \mathrm{Fe}, \mathrm{Na}$, and $\mathrm{K}(\mathrm{Kg}$ $\mathrm{ha}^{-1}$ year $^{-1}$ ) and rainfall depth for some individual species. However, a negative relationship was observed between the net flux of $\mathrm{Mn}, \mathrm{Zn}$, and $\mathrm{Mg}$ and rainfall depth, but only for $A$. rigidula.

The relationships between the mean concentration for most solutes $(\mathrm{K}, \mathrm{Mg}, \mathrm{Na}, \mathrm{Fe}, \mathrm{Mn}$, and $\mathrm{Cu}$ ) and rainfall depth fitted well with the negative reciprocalpower functions with negative slopes (Table 3). These mathematical functions explain that the concentration 
Fig. 2 Average seasonal concentrations and confidence intervals $(\alpha=0.05)$ of $\mathrm{Ca}, \mathrm{Mg}, \mathrm{K}$ and $\mathrm{Na}$ in gross rainfall and throughfall of four planted species of northeastern Mexico (means with different letter are statistically significant)
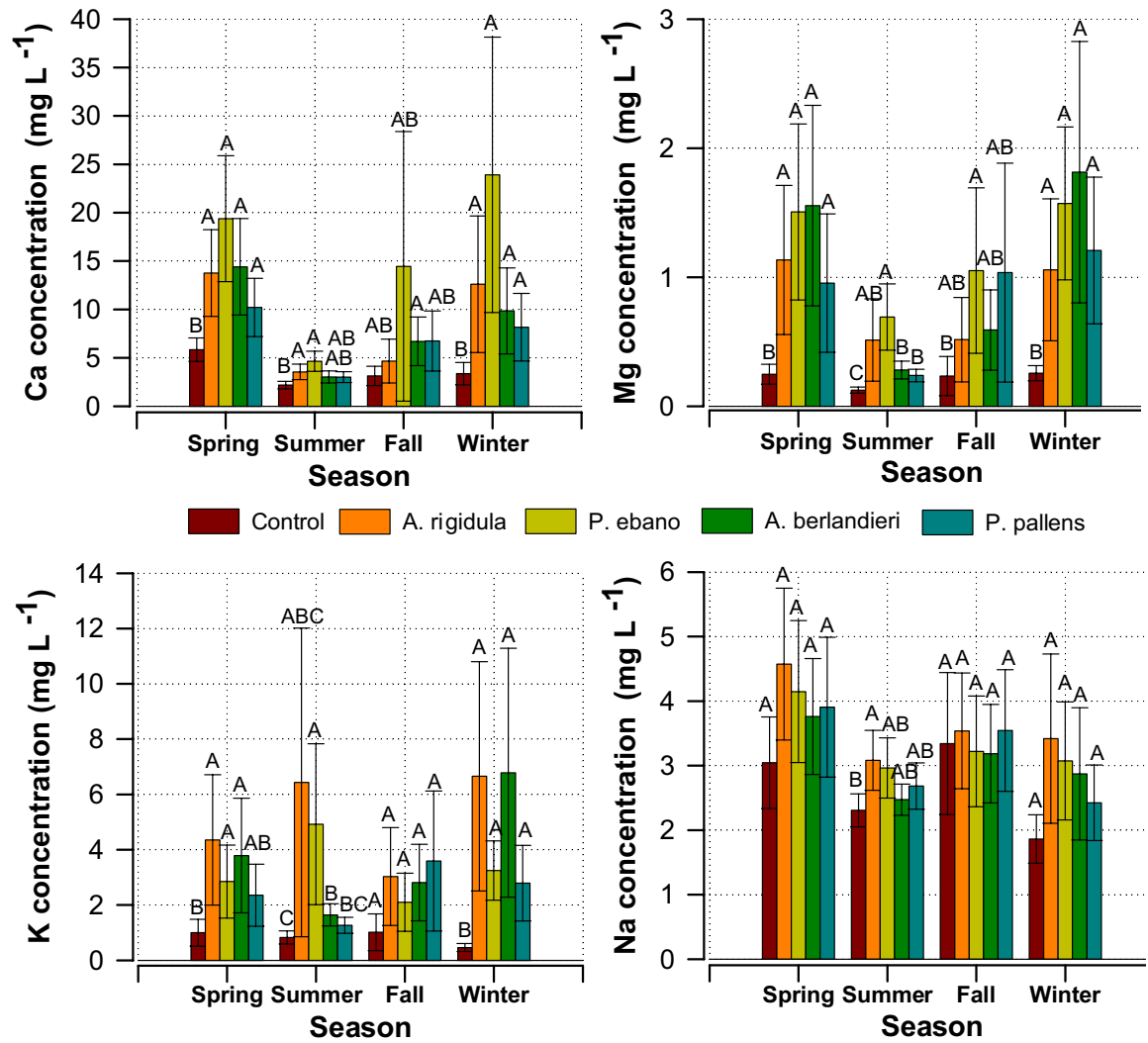

of most solutes decays quickly with small increments in rainfall depth indicating that rainfall depth washes most of the chemical solutes from the canopies with small rainfall depths. Further rainfall depth increments reduce constituent concentrations probably by dilution.

The relationship between the concentration $\left(\mathrm{mg} \mathrm{L}^{-1}\right)$ of several chemical solutes and lag time between rainfall events was positive for $\mathrm{Na}, \mathrm{Fe}, \mathrm{Zn}, \mathrm{Mn}, \mathrm{Cu}$, $\mathrm{Ca}$, and $\mathrm{K}$ for several plant species and negative for Mn (A. berlandieri, P. ebano and P. pallens). In fact, the mean concentration of $\mathrm{Ca}, \mathrm{Mg}$ and $\mathrm{Na}$ and lag time between rainfalls (days) fitted well with positive linear relationships (Table 3). That is, the solute concentration increases with the lag time between rainfalls.

\section{Discussion}

Total rainfall for the study period from March 1996 to March 1997 was $523 \mathrm{~mm}$, and it is considered to be a dry year since mean annual rainfall depth for the region is $760 \mathrm{~mm}$ with a standard deviation of $260 \mathrm{~mm}$ (Návar et al. 1999). That is, assuming that the annual rainfall distributes normally, there is only an $18 \%$ probability of occurrence of a year with less than $523 \mathrm{~mm}$ of rainfall depth. Regardless of the small rainfall depth, similar observations on interception loss were reported at the individual species level (Návar and Bryan 1990; 1994) as well as at the plant community scale (Návar et al. 1999) for the Tamaulipan thornscrub, which included the plant species observed in this research. At the species level, differences were observed and partially associated with total aboveground biomass. Shrubs with large surface areas of foliage and branches serve to intercept and redistribute rainfall below the canopies. Schroth et al. (2001) also observed statistical differences in throughfall among semi-arid plant species in tree-based land use systems and spontaneous tree vegetation in Central Amazonia and Breman and Kessler (1995) did so in the semi-arid plants of agroecosystems in the Sahelian countries. 
Fig. 3 The average seasonal concentrations and confidence intervals $(\alpha=0.05)$ of $\mathrm{Cu}, \mathrm{Mn}, \mathrm{Fe}$ and $\mathrm{Zn}$ in gross rainfall and throughfall of four planted species of northeastern Mexico (means with different letter are statistically significant)
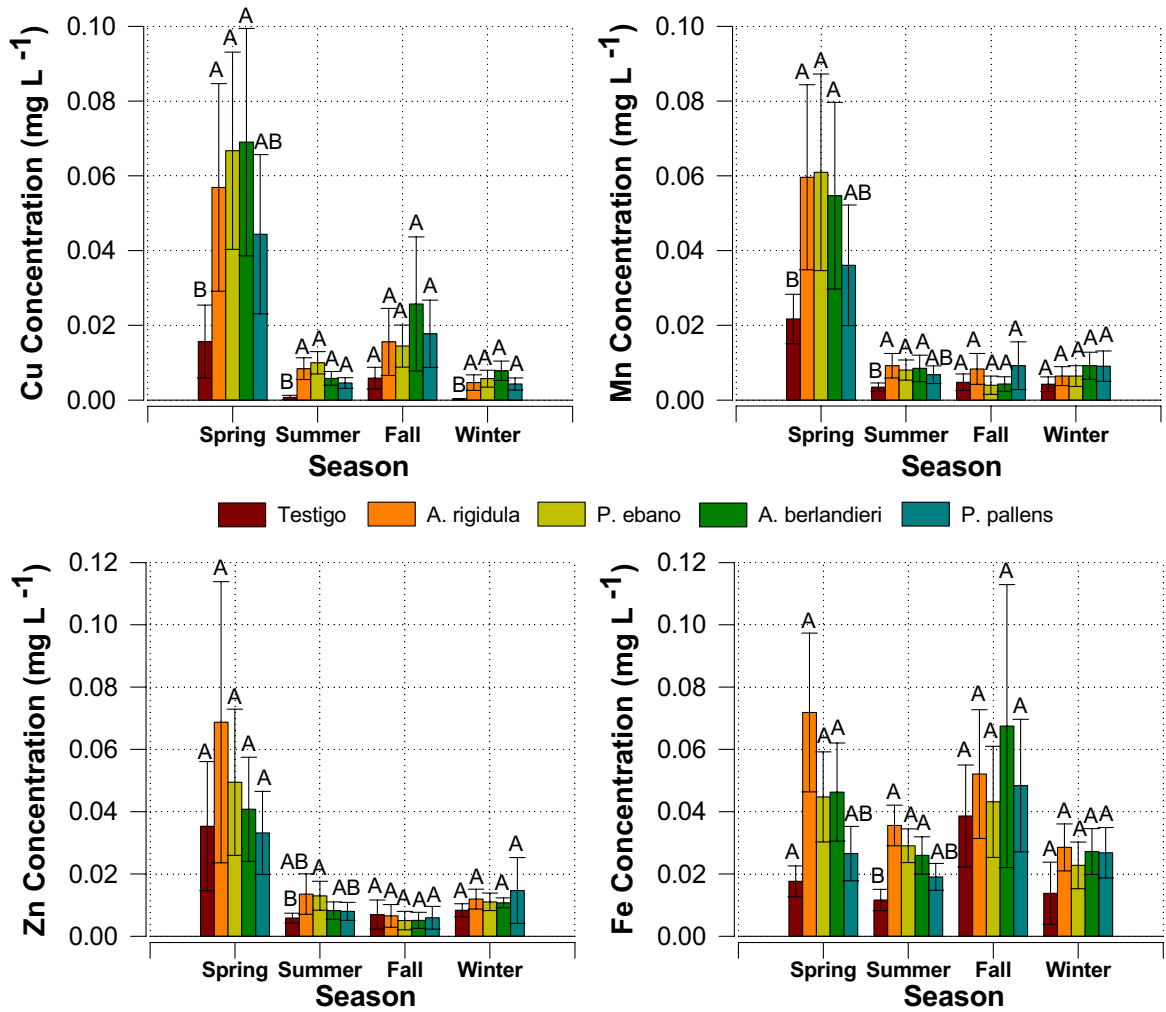

Season
The species from semi-arid region played an important role in chemically enriching throughfall, as this has also been found in other ecosystems (Borken et al. 2004; Rothe et al. 2002). Shrubs have foliage and branches exposed to wind that serve as traps for dust and natural particle emissions; the sticky exudates from some species may enhance their capacity to collect dust. Other sources of chemicals in

Table 3 The mathematical functions to predict the mean concentration $\left(\mathrm{mg} \mathrm{L}^{-1}\right)$ of several solutes as a function of rainfall depth and lag time between rainfalls

\begin{tabular}{|c|c|c|c|}
\hline Constituent concentration & Mathematical function & $\mathrm{R}^{2}$ & Probability $p=1-\int_{F=0}^{F=F} f(F) \partial F$ \\
\hline $\mathrm{Ca}$ & $\frac{1}{0.090\left(\frac{1}{R D}\right)^{-0.43}}$ & 0.34 & 0.0001 \\
\hline K & $\frac{1}{0.259\left(\frac{1}{R D}\right)^{-0.48}}$ & 0.29 & 0.0018 \\
\hline $\mathrm{Mg}$ & $\frac{1}{0.807\left(\frac{1}{R D}\right)^{-0.65}}$ & 0.44 & 0.0001 \\
\hline $\mathrm{Na}$ & $0.15-0.138 \operatorname{Ln} \frac{1}{R D}$ & 0.54 & 0.0001 \\
\hline $\mathrm{Fe}$ & $\frac{1}{24.68\left(\frac{1}{R D}\right)^{-0.44}}$ & 0.27 & 0.0025 \\
\hline $\mathrm{Cu}$ & $\frac{1}{50.53\left(\frac{1}{R D}\right)^{-0.02}}$ & 0.31 & 0.0001 \\
\hline $\mathrm{Zn}$ & $\frac{1}{68.19\left(\frac{1}{R D}\right)^{-0.41}}$ & 0.16 & 0.021 \\
\hline $\mathrm{Ca}$ & $4.99+0.46 L T$ & 0.25 & 0.0032 \\
\hline $\mathrm{Mg}$ & $0.53+0.035 L T$ & 0.13 & 0.046 \\
\hline $\mathrm{Na}$ & $2.58+0.065 L T$ & 0.16 & 0.039 \\
\hline
\end{tabular}

Where: $\mathrm{RD}=$ Rainfall depth $(\mathrm{mm})$; LT $=$ Lag time (days), $\mathrm{f}(\mathrm{F})$ is the mathematical function for the F-Fisher probability density function 
throughfall include canopy exchange, which appeared to control throughfall input of solutes. Canopy leaching fluxes have also dominated solute input in contrast to dry deposition in other forest ecosystems (Devlaeminck et al. 2005; Zhang et al. 2006). Henceforth, the chemical interaction among rainfall, dry deposition, sticky exudations and canopy leaching is probably the main cause of throughfall enrichment with most solutes for most seasons.

In this study, coarse estimates indicate that canopy leaching contributed with $83 \%$ of the total net throughfall solute input. In places where canopy exchange dominates solute input, the enrichment of throughfall has been described by numerous processes. For example, increased $\mathrm{Cu}$ solutes in throughfall have been explained by the internal leaching of this element (Marschner 1986; Mengel and Kirkby 1982). Several investigators (Parker 1983; Poszwa et al. 2000; Santa Regina et al. 1997; Tukey 1970) suggest that the mobility of $\mathrm{Ca}, \mathrm{Mg}$, and $\mathrm{K}$ inside leaf tissue may explain the high concentrations measured in throughfall compared to gross precipitation. Indeed, foliar analysis indicated that the leaves of $P$. ebano had the highest Ca concentrations (Pérez 1997), stressing that the chemical interaction of rainfall with leaves could be another potential throughfall source, via the chemical exchange between plant tissue and gross rainfall. Pérez (1997) also observed high $\mathrm{Mg}$ concentrations in the leaves of P. ebano. Csikkel and Kiss (1997) concluded that the high Mg concentrations in the leaves of Pinus sylvestris were the result of the increased autophosphorylation of the Kinase protein. Calcium appears to be the dominant cation flux in throughfall in other ecosystems as well (Crockford et al. 1996; Knops et al. 1996), and it is specifically important in acidic and calcareous soils where a preferential translocation of $\mathrm{Ca}$ from roots to leaves occurs (Poszwa et al. 2000). On the other hand, Potter et al. (1991) suggested that the chemical reaction between anions may explain the increased concentrations of $\mathrm{Ca}$ below the canopies.

Dry deposition has been found to also be an important source of several solutes in other ecosystems (Ignatova 1995). Several investigators have proposed that dry fallout between storms dominates the chemical input in throughfall (Fenn and Bytnerowicz 1997; Fenn et al. 2000). Air concentrations are related (amongst other things) to dust emissions associated with traffic on unpaved roads or agricultural tillage, and natural particle emissions. Therefore surface area and form of the canopy are prime factors influencing throughfall chemistry that may explain the largest net flux contribution of $P$. ebano and A. berlandieri. In general, shrubs with the largest aboveground biomass components produced the largest total annual fluxes for all chemicals measured in this study.

Total and net fluxes are a function of total biomass. Therefore, statistical relationships were noted between chemical fluxes and total aboveground biomass. Wang and Klinka (1997) observed that K concentrations in leaves were statistically correlated in a positive manner with tree top height and diameter at breast height, partially explaining the importance of biomass interception of dry deposition and canopy leaching.

The relationships between solute concentration and rainfall depth and lag time between storms resulted in reciprocal and linear relationships, respectively. The former equations indicate that most chemical solutes are washed off the canopies with little rainfall depth and that eventually the concentration levels off. The steady state appears to be controlled by the chemical solute concentration in bulk rainfall and probably by the canopy leaching processes. The positive relationships between the chemical solute concentration and lag time between rainfall events explain the amount of intercepted emissions and probably exudates from plant tissue. This relationship has been explained in terms of the time canopies have to intercept dust from biomass components (Wedding et al. 1976). In this process, the exudation of several chemicals from leaves to intercept dust emissions and to chemically interact with rainfall must not be ruled out. Several researchers have proposed to use the statistical parameters of these relationships to explain the sources of net flux (Lovett and Lindberg 1984; Neary and Gizyn 1994; Puckett 1990). Lovett et al. (1996) and Schreiber et al. (1990) have suggested that in addition to rainfall depth and lag time between rains, $\mathrm{H}^{+}$concentrations in rainfall play an important role in increasing throughfall concentrations of most solutes.

Sources of chemicals in throughfall by dry deposition are explained by the air masses dominating the landscapes of northeastern Mexico. In the region of Linares, air masses called 'huastecos' and 'nortes' dominate during most of the year and sporadically during the winter-spring season, respectively. Warm, 
wet air masses, called 'huastecos' originating in the Atlantic Ocean and Gulf of Mexico and transported by easterlies, appear to explain the large $\mathrm{K}, \mathrm{Na}, \mathrm{Cu}$, and $\mathrm{Fe}$ concentrations in gross rainfall and throughfall during the summer. This has also been reported in other ecosystems dominated by similar air masses by Brown and Lles (1991), Crockford et al. (1996) and Waring and Schlesinger (1985). Sodium e.g., is commonly dissolved in precipitation which falls along ocean coasts, (Linares is just $300 \mathrm{~km}$ away from the coast of the northern Gulf of Mexico) or chemicals may adhere to dust particles which become temporarily suspended in the atmosphere and return to the soil as dry fallout between storms.

The 'nortes' may also explain the high concentration of most cations in gross rainfall and throughfall which were recorded during the spring and winter seasons. At this time, the concentrations of most solutes are high due to a combination of rainfall with small depths and the amount of dry deposition. It is likely that rainfall depth is limiting when considered to wash most dry deposition from branches and stems. This is noted mainly in the concentrations of $\mathrm{Cu}, \mathrm{Mn}$ and $\mathrm{Zn}$ during spring. During winter and spring, the cold, highpressure air masses coming from the north may bring dust from the Metropolitan Area of Monterrey and farther places up north since Domingos et al. (1995) observed that several solutes were more abundant in areas of high air contamination. Specifically, the solutes $\mathrm{Ca}$ (spring and winter), $\mathrm{Mg}$ (spring and winter), $\mathrm{K}$ (winter), $\mathrm{Na}$ (spring), $\mathrm{Cu}$ (spring), Mn (spring), and $\mathrm{Zn}$ (spring) increased concentrations in rainfall and throughfall in contrast to the rest of the seasons.

The semi arid, sub tropical soils are generally deficient of microelements such as $\mathrm{Zn}, \mathrm{Mn}, \mathrm{Fe}, \mathrm{Cu}$, and Mo (Vlek 1985). The addition of micronutrients as fertilizers increases crop productivity in arid and semi arid soils (Rashid and Ryan 2004). In the northeast of Mexico, shifting cultivation is a common land use with duration between rotations of 10 20 years. Loss of fertility is the main cause of land abandonment and peasants call this practice 'to let the land rest for a while'. Shrubs studied in this research are pioneer plant species that colonize first abandoned lands and their contribution to increase micronutrients in throughfall in contrast to rainfall was noted by the net flux equation. The net flux of $\mathrm{Cu}, \mathrm{Fe}$, and $\mathrm{Mn}$ was from one to close to three orders of magnitude in throughfall in contrast to the net flux in gross rainfall.
After plant establishes, soil nutrient recovers and the land is cleared again for crop production. Therefore, this research stresses the importance of native plant cover to increase micronutrient input, via throughfall, and mainly through canopy leaching processes, which is the largest flux in contrast to dry deposition.

\section{Conclusions}

Rainfall is an important source of chemical solute input $(\mathrm{Ca}, \mathrm{Na}, \mathrm{Mg}, \mathrm{K}, \mathrm{Mn}, \mathrm{Fe}, \mathrm{Zn}$, and $\mathrm{Cu}$ ), contributing with a total flux of $24.11 \mathrm{Kg} \mathrm{ha}^{-1} \mathrm{y}^{-1}$. However, the canopies of plant species also contributed with an average net flux of $13.72 \mathrm{Kg} \mathrm{ha}^{-1} \mathrm{y}^{-1}$. Chemicals and specific differences in throughfall chemistry stressed the differential contributions of air masses on the total and net fluxes of plant species. Although $\mathrm{Ca}, \mathrm{Na}$ and $\mathrm{K}$ dominated total flux, the net flux was controlled by $\mathrm{Cu}, \mathrm{Mg}$, and K. P. ebano recorded the highest and $A$. rigidula the smallest total and net fluxes. Total aboveground biomass partially explained the total and net fluxes stressing the effect of interception of dust and natural particle emissions and the intensity of canopy exchange processes. Rainfall depth and lag time between rainfall events explained part of the additional variation, stressing the importance of local and external sources of chemical solutes in throughfall of these semi-arid, subtropical species.

Acknowledgments The authors of this report wish to thank Elsa Gonzalez R. and Beatriz Rodriguez T. for their assistance in the chemistry analysis. Thanks are also given to the CONACYT-CONAFOR fund for partially funding this project through research grant 6231.

Open Access This article is distributed under the terms of the Creative Commons Attribution Noncommercial License which permits any noncommercial use, distribution, and reproduction in any medium, provided the original author(s) and source are credited.

\section{References}

Ambatzis E, Alifragis D, Papaioannou A, Orfanoudakis M (2003) Effects of shrubs (Calicotome villosa P. Link) on surface soil properties in degradation ecosystems of West Lesvos Island. J Int Res Publ 3:1-12

Borken W, Xu YJ, Beese F (2004) Ammonium, nitrate and dissolved organic nitrogen in seepage water as affected by 
compost amendment to European beech, Norway spruce and Scots pine forests. Plant Soil 258:121-134. doi:10.1023/B:PLSO.0000016543.36970.29

Breman H, Kessler J-J (1995) Woody plants in agro-ecosystems of semi-arid regions - with an emphasis on the Sahelian countries. Advanced Series in Agricultural Science 23, Springer, Berlin, Heidelberg, p 340

Brown AHF, Lles MA (1991) Water chemistry profiles under four tree species at Gisburn, NW England. For Oxf 64:169-187

Crockford RH, Richardson DP, Sageman R (1996) Chemistry of rainfall, throughfall and stemflow in a eucalypt forest and pine plantation in south-east Australia 2. Throughfall. Hydrol Process 10:1-11. doi:10.1002/(SICI)1099-1085 (199601)10:1<1::AID-HYP295>3.0.CO;2-V

Csikkel S, Kiss SA (1997) Changes in magnesium content of tree sprouts, determined monthly by atomic spectroscopy. Acta Agronomica Hung 45:127-133

Devlaeminck R, Schrijver AD, Hermy M (2005) Variation in throughfall deposition across a deciduous beech (Fagus sylvatica) forest edge in Flanders. Sci Total Environ 337:241-252. doi:10.1016/j.scitotenv.2004.07.005

Domingos M, Poggiani F, Vueno FS, Silveira-Lopez MI (1995) Pluvial precipitation and nutrient flux in the forest of biological reserve of Paranapiacaba, subject to air pollution from Cubatao, SP. Revista brasileña de Botanica 18:119-131

Fahey TJ, Yavitt JB, Joyce G (1988) Precipitation and throughfall chemistry in Pinus contorta spp. latifolia ecosystems, southeastern Wyoming. Can J For Res 18:337-345

Fenn ME, Bytnerowicz A (1997) Summer throughfall and winter deposition in the San Bernardino mountains in southern California. Atmos Environ 31:673-683. doi:10.1016/S1352-2310(96)00238-5

Fenn ME, Poth MA, Schilling SL, Grainger DB (2000) Throughfall and fog deposition of nitrogen and sulfur at an N-limited and N-saturated site in the San Bernardino mountains, southern California. Can J For Res 30:14761488. doi:10.1139/cjfr-30-9-1476

Filoso S, Williams MR, Melack JM (1999) Composition and deposition of throughfall in a flooded forest archipelago. Biogeochemistry 45:169-195

Gauquelin T, Fromard F, Badri W, Dagnac J (1992) Contribution of nutrient elements to the soil from litter, rainfall and throughfall in a Juniperus thurifera wood in the western High Atlas, Morocco. Ann For Sci 49:599-614. doi:10.1051/forest: 19920604

Germer S, Neill CV, Krusche A, Neto SCG, Elsenbeer H (2007) Seasonal and within-event dynamics of rainfall and throughfall chemistry in an open tropical rainforest (Rondônia, Brazil). Biogeochemistry 86:155-174. doi:10.1007/s10533-007-9152-9

Gesper PL, Holowaychuk N (1970) Effects of stemflow water on a Miami soil under a beech tree. I. Morphological a physical properties. Soil Sci Soc Am Proc 34:779-786

Ignatova N (1995) Changes in crown leaching composition induced by a sudden increase in atmospheric deposition. A case of study in South-Western Bulgaria. Plant Soil 168169:373-382. doi:10.1007/BF00029350

Jonsson K, Ong CK, Odongo JCW (1999) Influence of scattered Néré and karité trees on microclimate, soil fertility and millet yield in Burkina Faso. Exp Agric 35:39-53. doi:10.1017/S0014479799001039

Knops JMH, Nash TH, Schlesinger WH (1996) The influence of epiphytic lichens on the nutrition cycling of an oak woodland. Ecol Monogr 66:159-179. doi:10.2307/2963473

Lovett GM, Lindberg SE (1984) Dry deposition and canopy exchange in a mixed oak forest as determined by analysis throughfall. J Appl Ecol 21:1013-1027. doi:10.2307/ 2405064

Lovett GM, Nolan SS, Driscoll CT, Fahey TJ (1996) Factors regulating throughfall flux in a New Hampshire forested landscape. Can J For Res 26:2134-2144. doi:10.1139/x26242

Marschner H (1986) Mineral Nutrition of Higher Plants. Academic Press San Diego, Ca., p 649

Mengel K, Kirkby EA (1982) Principles of plant nutrition, 3rd edn. International Potash Institute, Switzerland, p 655

Mohr H, Schopfer P (1995) Plant Physiology. Springer Veralg, Berlin, Heidelberg

Návar J, Bryan R (1990) Interception loss and rainfall redistribution by three semi arid growing shrubs in northeastern Mexico. J Hydrol (Amst) 115:51-63. doi:10.1016/0022-1694(90)90197-6

Návar J, Bryan R (1994) Fitting the analytical model of rainfall interception of Gash to individual shrubs of semi-arid vegetation in northeastern Mexico. Agric For Meteorol 68:133-143. doi:10.1016/0168-1923(94)90032-9

Návar J, Cavazos T, Domínguez PA (1994) Los balances hidrológicos mensuales con tres probabilidades del estado de Nuevo León. En C. Pola S., J.A. Ramírez F., M.M. Rangel, \& I. Navarro-L. (Eds) Actas Fac. Ciencias de la Tierra UANL Linares, 8:71-82

Návar J, Charles F, Jurado E (1999) Spatial variations of interception loss components by Tamaulipan thornscrub in northeastern Mexico. For Ecol Manage 124:231-239. doi:10.1016/S0378-1127(99)00077-8

Návar J, Méndez E, Nájera A, Graciano J, Dale V, Parresol B (2004) Biomass equations for shrub species of Tamaulipan thornscrub of North-eastern Mexico. J Arid Environ 59:657-674. doi:10.1016/j.jaridenv.2004.02.010

Neary AJ, Gizyn WT (1994) Throughfall and stemflow chemistry under deciduos and coniferous forest canopies in south-central Ontario. Can J For Res 24:1089-1100. doi:10.1139/x94-145

Newman EI (1995) Phosphorus inputs to the ecosystems. J Ecol 83:713-726. doi: $10.2307 / 2261638$

Parker GG (1983) Throughfall and stemflow in the forest nutrient cycle. Adv Ecol Res 13:57-133. doi:10.1016/ S0065-2504(08)60108-7

Pérez RM (1997) Valor Nutricional foliar de tres especies de Acacia. Tesis de Maestría. Facultad de Ciencias Forestales, UANL, Linares, N.L. Mexico, p 100

Poszwa A, Dambrine E, Pollier B, Atteia O (2000) A comparison between $\mathrm{Ca}$ and $\mathrm{Sr}$ cycling in forest ecosystems. Plant Soil 225:299-310. doi:10.1023/A:1026570812307

Potter CS, Ragslade HL, Swank WT (1991) Atmospheric deposition and foliar leaching in a regenerating southern Appalachian forest canopy. J Ecol 79:97-115. doi: $10.2307 / 2260786$

Puckett LJ (1990) Estimates of ion sources in deciduous and coniferous throughfall. Atmos Environ 24:545-555 
Rashid A, Ryan J (2004) Micronutrient constraints to crop production in soils with Mediterranean-type characteristics: A review. J Plant Nutr 27:959-975. doi:10.1081/ PLN-120037530

Romero FG (1999) Caracterización ecológica y definición de esquemas de muestreo en el matorral espinoso tamaulipeco del nordeste de México. Tesis de Maestría en Ciencias Forestales. Facultad de Ciencias Forestales, UANL, Linares, N.L., México

Rothe A, Huber C, Kreutzer K, Wendelin W (2002) Deposition and soil leaching in stands of Norway Spruce and European beech: results from the Hoglwald research in comparison with other European case studies. Plant Soil 240:33-45. doi:10.1023/A:1015846906956

Santa Regina L, Rico M, Rapp M, Gallego HA (1997) Seasonal variations in nutrient concentration in leaves and branches of Quercus pyrenaica. J Veg Sci 8:651-654. doi:10.2307/ 3237369

Schade JD, Hobbie SE (2005) Spatial and temporal variation in islands of fertility in the Sonoran Desert. Biogeochemistry 73:541-553. doi:10.1007/s10533-004-1718-1

Schreiber JD, Duffy PD, McDowell LL (1990) Nutrient leaching of a loblolly pine forest floor by simulated rainfall. I. Intensity effects. For Sci 36:765-776

Schlesinger WH, Pilmanis AM (1998) Plant-soil interactions in deserts. Biogeochemistry 42:169-187. doi:10.1023/ A:1005939924434

Schroth G, Elias MEA, Uguen K, Seixas R, Zech W (2001) Nutrient fluxes in rainfall, throughfall and stemflow in tree-based land use systems and spontaneous tree vegetation of central Amazonia. Agric Ecosyst Environ 87:3749. doi:10.1016/S0167-8809(00)00294-2

Switzer GL, Nelson LE, Shelton MG (1988) Influence of the canopy of loblolly pine plantations on the deposition and chemistry of precipitation. Technical Bulletin Mississippi Agricultural and Forestry Experiment Station. No. 154, pp 30

Su Y, Shao H, Zhang T (2002) Influencing mechanism of several shrubs and subshrubs on soil fertility in Keerquin sandy land. J Appl Ecol 13:802-806
Tobón C, Sevink J, Verstraten JM (2004) Solute fluxes in throughfall and stemflow in four forest ecosystems in northwest Amazonia. Biogeochemistry 70:1-25. doi:10.1023/B:BIOG.0000049334.10381.f8

Tukey HB (1970) The leaching of substances from plants. Annu Rev Plant Physiol 21:305-329. doi:10.1146/ annurev.pp.21.060170.001513

Vlek PLG (1985) Micronutrients in Tropical Food Crop Production. Springer Veralg, Berlin, Germany

Wang GG, Klinka K (1997) White spruce foliar nutrient concentrations in relation to tree growth and soil nutrient amounts. For Ecol Manage 98:89-99. doi:10.1016/S03781127(97)00048-0

Waring RH, Schlesinger WH (1985) Forest Ecosystems, Concept and Management. Academic Press, Inc., Orlando, Florida, p 340

Wedding JB, Carlson RW, Stukel JJ, Bazzaz FA (1976) Aerosol deposition onto plant leaves. Environ Sci Technol 9:151153. doi:10.1021/es60100a004

Wezel A, Rajo JL, Herbrig C (2000) Influence of shrubs on soil characteristics and their function in the Sahelian agroecosystems in semi-arid Niger. J Arid Environ 44:383398. doi:10.1006/jare.1999.0609

Whitford WG, Anderson J, Rice PM (1997) Stemflow contribution to the 'fertile island' effect in creosote bush, Larrea tridentata. J Arid Environ 35:451-457. doi:10.1006/jare.1996.0164

Woerner MP (1991) Métodos químicos para el análisis de suelos calizos de zonas áridas y semiáridas. Facultad de Ciencias Forestales, UANL, Linares, N.L., México, p 105

Zhang G, Zeng GM, Jiang YM, Du CY, Huang GH, Yao JM, Zeng M, Zhang XL, Tan W (2006) Seasonal dry deposition and canopy leaching of base cations in a subtropical evergreen mixed forest, China. Silva Fenn 40:417-428

Zimmermann A, Wilcke W, Elsenbeer H (2007) Spatial and temporal patterns of throughfall quantity and quality in a tropical montane forest in Ecuador. J Hydrol (Amst) 343:80-96. doi:10.1016/j.jhydrol.2007.06.012 